\title{
PERBEDAAN METODE PRICING, KEBERAGAMAN PRODUK TERHADAP KEPUASAN KONSUMEN PASAR TRADISIONAL
}

\author{
Donny Arif, Nikma Yucha, Ratna Ekasari, Wulan Purnamasari \\ Fakultas Ekonomi dan Bisnis, Program Studi Strata I Manajemen \\ Universitas Maarif Hasyim Latif Sidoarjo, Indonesia \\ e-mail: donny_arif@dosen.umaha.ac.id,nikma@dosen.umaha.ac.id, \\ ratna_ekasari@umaha.ac.id,wulan_purnamasari@dosen.umaha.ac.id
}

\begin{abstract}
Traditional markets are one of the economic gathering points of the community. While traditional markets are identical to slums, smells, dirty and so on. The need for a traditional market development strategy so that traditional markets remain the choice of buyers to shop for their daily needs. Market development is indeed not easy, market revitalization costs a lot. Markets that want to develop with government assistance through revitalization policies should not only produce progress that seems physically comfortable. This type of research in writing research is field research, which is a study conducted at the location of research by making observations about a phenomenon in a scientific state. Whereas in data collection in research using collection methods with observation, interviews and questionnaires. This study uses quantitative analysis methods. The location of the study was carried out at the Krisna Madubronto Sidorejo Krian market. The results of this study aim to find out and analyze the influence of price perceptions, product diversity and location on customer satisfaction in Madubronto Market, Sidoarjo city.
\end{abstract}

Keywords: effect of perceived price, product diversity and location on customer satisfaction traditional market

\section{PENDAHULUAN}

Pada perkembangan di era ini persaingan perdagangan semakin ketat memasarkan produk dan jasa. Pasar tradisional agar bisa bertahan dan meningkat maka harus mengetahui konsumennya secara komprehensif karena pasar tuntutan suatu produk dan jasa ialah konsumen. Dan salah satu kelebihan pasar tradisional ialah harga yang dijualkan para pedagang dapat ditawarkan pembeli. Sehingga harga yang terjadi merupakan persetujuan dari penjual dan pembeli. Pelaksanaan strategi pemasaran yang benar dapat membawa pelanggan atau konsumen untuk membuat suatu keputusan pembelian. Masyarakat saat ini yang semakin modern karena gaya hidup yang semakin lama semakin konsumtif menuntut untuk dapat meningkatkan minat belinya memperoleh suatu produk. Sidoarjo memiliki masyarakat yang banyak ragam kelas sosial, agama, latar belakang pendidikan, pekerjaan dan pendapatannya, sehingga dalam menghadapi kondisi saat ini akan terdapat banyak sekali jawaban yang tentu saja berbeda antara satu dengan lainnya tergantung pada faktor kebutuhan.

Harga di pasar modern yang pada umumnya sudah ditetapkan tanpa penawaran sehingga keuntungan relatif lebih baik dari pada pasar tradisional yang harganya berubah-ubah dengan sistem penawarannya. Harga yang tidak konsisten, terkadang murah dalam penawaran namun kadang juga hampir sama dengan toko sehingga tergantung pandai-pandainya konsumen dalam menawar. Kondisi semacam itu membuat harga 
menjadi kurang bersaing dibandingkan pasar modern. Harga yang diberikan di pasar tradisional juga hampir tidak jauh beda dengan toko dan pasar modern di luar pasar meskipun masih bisa ditawar oleh konsumen. Harga bisa berubah sewaktu-waktu sehingga konsumen juga berpikir dua kali dalam memperkuat minat belinya pada pasar krisna Madubronto kabupaten Sidoarjo. Pasar tradisional yang seolah masih mempertahankan kondisi sederhananya. Pasar tradisional yang rata-rata menampilkan kondisi lingkungan yang kurang bersih. Produk yang sebagian tidak diberi kemasan serta kebersihan yang kurang diperhatikan sehingga kurang higienis. Kondisi pasar tradisional yang demikian membuat pasar tradisional kini tersaingi oleh pasar modern yang selalu melakukan peningkatan potensi yang dimilikinya.

Pasar menurut Assauri dalam Jurnal Fure, Hendra (2013), mulanya istilah pasar dikaitkan dengan pengertian tempat pembeli dan penjual bersama-sama melangsungkan pertukaran. Pasar Krisna Madubronto merupakan salah satu pasar yang ada di kota Sidoarjo yang mempertahankan keadaan alami pasar tradisional dengan sudutsudut lokasi yang masih becek dengan kios-kios yang kurang teratur. Penataan ruang yang kurang rapi membuat keberagaman produk yang ditampilkan juga kurang menarik. Keberadaan pasar Krisna Madubronto adalah kebutuhan yang tak dapat dipisahkan dari masyarakat Sidoarjo dalam memenuhi kebutuhan sehari-hari. Keberadaan yang strategis, yang berada tepat bersebelahan dengan jalan alternatif menuju jalan utama ke jalan raya ini menjadikan pasar Krisna Madubronto menjadi pasar yang mudah untuk diakses dari berbagai daerah sekitar Madubronto Sidoarjo. Namun di tengah persaingan harga di pasar modern yang pada umumnya sudah ditetapkan tanpa penawaran sehingga keuntungan relatif lebih baik dari pada pasar tradisional yang harganya berubah-ubah dengan sistem penawarannya. Harga yang tidak konsisten, terkadang murah dalam penawaran namun kadang juga hampir sama dengan toko, sehingga tergantung pandai-pandainya konsumen dalam menawar. Kondisi semacam itu membuat harga menjadi kurang bersaing dibandingkan pasar modern. Harga yang diberikan di pasar tradisional juga hampir tidak jauh beda dengan toko dan pasar modern di luar pasar meskipun masih bisa ditawar oleh konsumen. Harga bisa berubah sewaktu-waktu sehingga konsumen juga berpikir dua kali dalam memperkuat minat belinya pada pasar Krisna Madubronto kabupaten Sidoarjo.

Berdasarkan permasalahan tersebut maka salam upaya mencapai tujuan penelitian ini, yaitu untuk mengetahui besarnya pengaruh persepsi harga, keberagaman produk dan lokasi terhadap kepuasan konsumen, peneliti membuat penelitian dengan judul Pengaruh Persepsi Harga, Keberagaman Produk, dan Lokasi Terhadap Kepuasan Konsumen di Pasar Krisna Madubronto Kabupaten Sidoarjo".

Pertanyaan penelitian yang merupakan bentuk penguraian atas rumusan masalah sebagai berikut.

1. Apakah persepsi harga berpengaruh positif dan signifikan terhadap kepuasan konsumen pada Pasar Krisna Madubronto Kabupaten Sidoarjo?

2. Apakah keberagaman produk berpengaruh positif dan signifikan terhadap kepuasan konsumen pada Pasar Krisna Madubronto Kabupaten Sidoarjo?

3. Apakah lokasi berpengaruh positif dan signifikan terhadap kepuasan konsumen pada Pasar Krisna Madubronto Kabupaten Sidoarjo?

4. Apakah persepsi harga, keberagaman produk dan lokasi secara simultan berpengaruh positif 
dan signifikan terhadap kepuasan konsumen pada Pasar Krisna Madubronto Kabupaten Sidoarjo?

\section{Landasan Teori}

Menurut Swastha (2003), harga merupakan komponen yang sangat berpengaruh langsung untuk proses penentuan di mana seseorang akan berbelanja.

Hartini, dan Muryani (2008), produk merupakan keperluan pokok seperti makanan dan minuman, konsumen akan mempertimbangkan kualitasnya, karena merupakan kebutuhan pokok dan yang berhubungan dengan kesehatan manusia, maka dari itu kualitas produk sangat memengaruhi konsumen mengambil keputusan pembelian produk.

Kotler dan Keller (2009) mengartikan lokasi merupakan sarana aktivitas perusahaan agar produk mudah didapatkan oleh konsumen yang merupakan sasarannya.

Zeithaml dan Bitner (2000) mengartikan kepuasan ialah respons atau tanggapan konsumen mengenai pemenuhan kebutuhan untuk memenuhi harapan mereka.

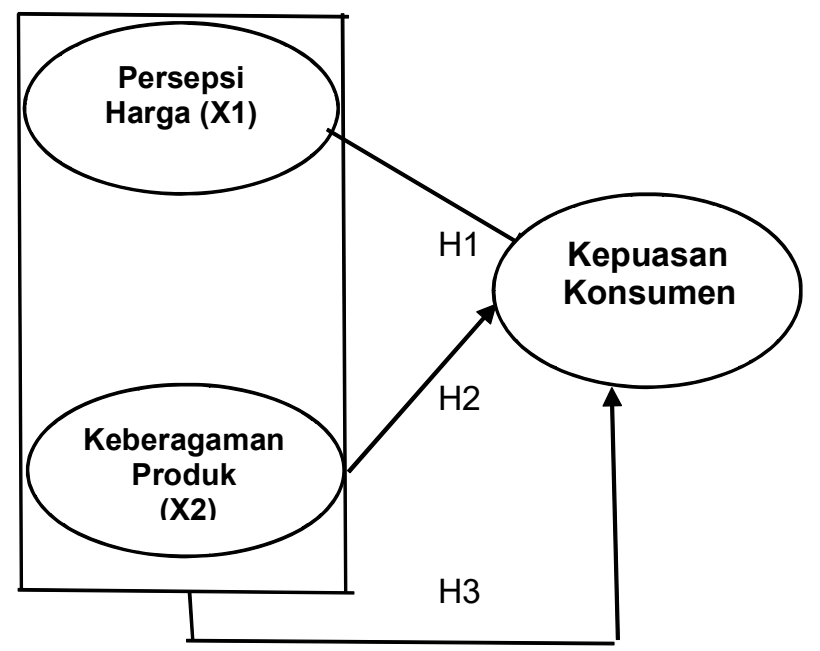

Gambar 1 Kerangka Konseptual

Sumber: Oleh Peneliti

\section{Kerangka Konseptual}

Kerangka konseptual pada penelitian ini menggambarkan hubungan dari tiga independen variabel persepsi harga (X1), keberagaman produk (X2) dan lokasi (X3), serta satu variabel dependen kepuasan konsumen (Y). Kerangka konseptual tersebut dapat dilihat pada Gambar 1.

\section{METODE PENELITIAN}

\section{Objek dan Ruang Lingkup Penelitian}

Adapun ruang lingkup ini meliputi persepsi harga, keberagaman produk dan lokasi sebagai variabel bebas atau independen dan kepuasan konsumen sebagai variabel terikat dependen. Variabel bebas tersebut akan dianalisis seberapa besar variabel-variabel tersebut memengaruhi proses kepuasan konsumen (variabel terikat) di Pasar Krisna Madubronto Kabupaten Sidoarjo.

\section{Metode Penelitian}

Data penelitian yang akan digunakan yaitu metode penelitian Kuantitatif. Data ini diperoleh dari populasi dan sampel berupa angka. Serta pengumpulan data dengan cara menyebarkan kuesioner secara langsung kepada responden dan dengan wawancara tujuannya untuk mengetahui bagaimana tanggapan konsumen di Pasar Krisna Madubronto Kabupaten Sidoarjo.

Populasi penelitian ini adalah para konsumen yang ada di Pasar Krisna Madubronto Kabupaten Sidoarjo yang tidak bisa dihitung jumlah pastinya, karena pertimbangan populasi yang terlalu banyak, serta keterbatasan biaya dan waktu.

Sampel yang akan digunakan menjadi objek penelitian ini ialah kurang lebih 150 konsumen di pasar Krisna Madubronto Kabupaten Sidoarjo. 
Konsumen yang telah melakukan pembelian minimal 3 kali pembelian di Pasar Krisna Mandubronto dianggap lebih mengerti dengan baik bagaimana persepsi harga, keberagaman produk dan lokasi yang memengaruhi kepuasan konsumen di pasar tersebut. Teknik pengambilan sampel memakai Accidental Sampling. Menurut Sugiyono (2009:85), accidental sampling adalah teknik penentuan sampel berdasarkan kebetulan, yaitu konsumen yang secara kebetulan/insidental bertemu dengan peneliti dapat digunakan sebagai sampel, bila dipandang orang yang kebetulan ditemui itu cocok sebagai sumber data.

Dalam penelitian ini, penulis menggunakan metode regresi linier berganda dikarenakan variabelnya lebih dari satu, dan untuk memakai pengujian ini, penulis menggunakan software SPSS versi 23. Analisis regresi linier berganda digunakan untuk mengetahui pengaruh antarvariabel independen $(\mathrm{X})$ dan variabel dependen $(\mathrm{Y})$.

\section{Definisi Operasional Penelitian}

Tabel 1 Variabel dan Indikator

\begin{tabular}{|c|c|c|}
\hline Variabel & Notasi & Indikator \\
\hline \multirow[t]{4}{*}{$\begin{array}{l}\text { Presepsi } \\
\text { Harga }\end{array}$} & $\mathrm{X} 1.1$ & $\begin{array}{l}\text { Harga terjangkau oleh daya beli } \\
\text { konsumen }\end{array}$ \\
\hline & $\mathrm{X} 1.2$ & $\begin{array}{l}\text { Perbandingan harga lebih murah } \\
\text { pada harga pesaing }\end{array}$ \\
\hline & $\mathrm{X} 1.3$ & Kesesuaian kualitas harga \\
\hline & $\mathrm{X} 1.4$ & $\begin{array}{l}\text { Potongan harga produk yang } \\
\text { membuat konsumen membeli dan } \\
\text { berpengaruh dalam kepuasan } \\
\text { konsumen }\end{array}$ \\
\hline \multirow{3}{*}{$\begin{array}{l}\text { Keberagaman } \\
\text { Produk }\end{array}$} & $\mathrm{X} 2.1$ & Persediaan barang dagang \\
\hline & $\mathrm{X} 2.2$ & $\begin{array}{l}\text { Menentukan persediaan dalam } \\
\text { penampilan produk }\end{array}$ \\
\hline & $\mathrm{X} 2.3$ & Siklus persediaan ukuran produk \\
\hline \multirow[t]{3}{*}{$\begin{array}{l}\text { Kepuasan } \\
\text { Konsumen }\end{array}$} & Y.1 & $\begin{array}{l}\text { Harga yang ditawarkan dan } \\
\text { sangat puas dengan produk yang } \\
\text { dibeli }\end{array}$ \\
\hline & Y.2 & $\begin{array}{l}\text { Kebutuhan untuk membeli } \\
\text { produk }\end{array}$ \\
\hline & Y.3 & $\begin{array}{l}\text { Merekomendasikan kepada } \\
\text { orang lain }\end{array}$ \\
\hline
\end{tabular}

Sumber: Data diolah Peneliti

\section{Pengumpulan data}

\section{Observasi}

Data diperoleh dengan disesuaikan berdasarkan pengamatan langsung pada objek yang di teliti dengan cara melihat, memperhatikan dan mendengar. Data yang didapatkan digunakan untuk mengungkapkan latar belakang dan mengidentifikasi masalah yang terkait dalam variabel yang diteliti.

\section{Kuesioner}

Memberikan pertanyaan tertulis kepada pelanggan yang berisi seputar masalah dan beberapa aspek yang akan diteliti. Penelitian ini menggunakan sumber data yang didapatkan dari hasil penyebaran kuesioner kepada responden yang berkunjung dan akan melakukan pembelian di Pasar Krisna Madubronto Sidoarjo. Peneliti dapat menyebarkan kuesioner kepada konsumen sambil memberikan pengarahan apabila ada halhal yang kurang dimengerti khususnya pada pertanyaan yang diajukan dalam kuesioner. Pertanyaan yang dimuat dalam kuesioner terkait dengan variabel harga, keberagaman produk dan lokasi dan kepuasan konsumen yang dikumpulkan jawabannya untuk kemudian diolah datanya. Skala pengukuran data yang akan digunakan adalah menggunakan pengukuran data Likert.

\section{Interview (Wawancara)}

Wawancara merupakan teknik pengumpulan data jika peneliti ingin membuat studi pendahuluan untuk mendapatkan permasalahan yang akan diteliti, dan memahami suatu hal dari responden. Dalam wawancara, selain harus mengambil instrumen sebagai arahan untuk wawancara, kemudian dengan pengumpulan data bisa menggunakan gambar, brosur dan lainnya 
yang bisa membantu pelaksanaan wawancara yang nantinya akan berjalan lancar. Adapun penelitian ini wawancara dengan konsumen yang ada di Pasar Krisna Madubronto Kabupaten Sidoarjo.

\section{HASIL DAN PEMBAHASAN}

\section{Gambaran Umum Pasar Krisna Madubronto}

Pasar Krisna Madubronto Kabupaten Sidoarjo berdiri sejak tahun 2005 didirikan oleh Bapak Sudar dan Ibu Saroh dan terletak di Dusun Madubronto Desa Sidorejo Kecamatan Krian Kabupaten Sidoarjo, Nama dari pasar tersebut terinspirasi dari putra putri beliau yang bernama Kris dan Hanna, dan dijadikan nama pasar tersebut dengan nama Pasar Krisna Madubronto. Pasar Krisna Madubronto dulunya merupakan pasar kecil yang dibangun oleh pemilik nya dengan tujuan memanfaatkan lahan kosong yang berada di sebelah rumah pemilik pasar tersebut. Pasar tersebut memiliki panjang 120 $\mathrm{m}$ dan lebar $75 \mathrm{~m}$ yang berada di tengah-tengah sebuah desa yang dikelilingi beberapa perumahan yang berada di kecamatan tersebut.

\section{Visi dan Misi Pasar Krisna Maubronto \\ Visi}

Terwujudnya pasar yang bersih, tertib, nyaman dan indah dalam memajukan ekonomi khususnya pedagang di pasar tersebut, serta memberikan kemudahan warga Kecamatan Krian untuk mencari bahan pokok kebutuhan sehari-hari dan keperluan rumah tangga lainnya.

\section{Misi}

Pasar Krisna Madubronto Kabupaten Sidoarjo memiliki misi sebagai berikut.
1. Menciptakan pasar yang bersih, indah dan nyaman, diakui oleh masyarakat khususnya pedagang dan pengguna pasar.

2. Menciptakan pasar sebagai pusat pemberdayaan ekonomi rakyat di sekitar pasar tersebut.

3. Meningkatkan sumber pendapatan dari pasar khususnya pedagang di pasar tersebut.

4. Melakukan pembenahan dan penataan kios dan fasilitas umum sebagai sumber potensi jasa pelayanan pasar.

5. Melaksanakan sistem informasi manajemen pengelolaan pasar secara profesional.

\section{Struktur Kepengurusan}

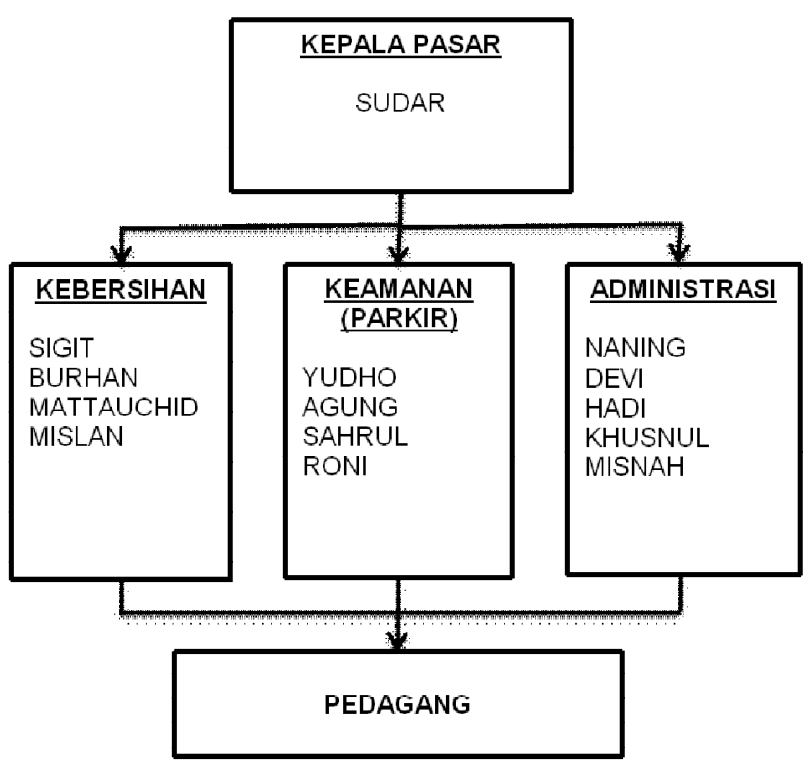

Gambar 2 Struktur Kepengurusan Pasar Krisna Madubronto Kabupaten Sidoarjo Sumber: Oleh peneliti

\section{Karakteristik Responden}

Tabel 2 Karakteristik Responden Berdasarkan Jenis Kelamin

\begin{tabular}{|c|l|c|c|}
\hline No. & Jenis Kelamin & Jumlah & Persentase \\
\hline 1. & Laki-Laki & 54 & $36,0 \%$ \\
\hline 2. & Perempuan & 96 & $64,0 \%$ \\
\hline Total & 150 & $100 \%$ \\
\hline
\end{tabular}




\section{Uji Validitas}

Apabila semua item dari setiap indikator mempunyai nilai yang signifikan $(\leq 0,05)$ maka dalam kuesioner menunjukkan nilai Valid sehingga dapat dilanjutkan sebagai instrument penelitian.

Uji instrumen yang telah dilakukan dengan menggunakan semua responden yang berjumlah 150. Hasil dari analisis dipaparkan pada tabel berikut ini.

\section{Tabel 2 Uji Validitas}

\begin{tabular}{|c|c|c|c|c|}
\hline Variabel & & Correlation & Sig. & Keterangan \\
\hline \multirow{9}{*}{$\begin{array}{c}\text { Persepsi } \\
\text { Harga (X1) }\end{array}$} & PH.1 1 &, $829 * *$ & 0,000 & Valid \\
\hline & PH.1_2 &, $873 * *$ & 0,000 & Valid \\
\hline & PH.1 3 &, $887^{* * *}$ & 0,000 & Valid \\
\hline & PH.2_1 &, $745^{* * *}$ & 0,000 & Valid \\
\hline & PH.2_2 & ,861** & 0,000 & Valid \\
\hline & PH.2_3 &, $894 * *$ & 0,000 & Valid \\
\hline & PH.3_1 & ,899** & 0,000 & Valid \\
\hline & PH.3_2 & $812^{* * *}$ & 0,000 & Valid \\
\hline & PH.3_3 &, $833 * *$ & 0,000 & Valid \\
\hline \multirow{9}{*}{$\begin{array}{c}\text { Keberagaman } \\
\text { Produk (X2) }\end{array}$} & KP.1_1 & ,904** & 0,000 & Valid \\
\hline & KP.1_2 & ,914** & 0,000 & Valid \\
\hline & KP.1_3 &, $867 * *$ & 0,000 & Valid \\
\hline & KP.2_1 & ,905** & 0,000 & Valid \\
\hline & KP.2_2 &, $800^{* * *}$ & 0,000 & Valid \\
\hline & KP.2 3 & ,889** & 0,000 & Valid \\
\hline & KP.3 1 &, $888 * *$ & 0,000 & Valid \\
\hline & KP.3 2 & $894^{* * *}$ & 0,000 & Valid \\
\hline & KP. 33 & ,896** & 0,000 & Valid \\
\hline \multirow{9}{*}{$\begin{array}{l}\text { Kepuasan } \\
\text { Konsumen } \\
\text { (Y) }\end{array}$} & KK.1 1 &, $824^{* * *}$ & 0,000 & Valid \\
\hline & KK.1_2 &, $844 * *$ & 0,000 & Valid \\
\hline & KK.1_3 & $849^{* * *}$ & 0,000 & Valid \\
\hline & KK.2_1 &, $842^{* * *}$ & 0,000 & Valid \\
\hline & KK.2_2 &, $863 * *$ & 0,000 & Valid \\
\hline & KK.2_3 & , $777^{* * *}$ & 0,000 & Valid \\
\hline & KK.3_1 & $818^{* * *}$ & 0,000 & Valid \\
\hline & KK.3_2 & ,899** & 0,000 & Valid \\
\hline & KK.3_3 & ,900** & 0,000 & Valid \\
\hline
\end{tabular}

Sumber: Lampiran Output SPSS Pengujian Uji Validitas (data diolah peneliti)

Dari tabel tersebut, hasil pada uji validitas mengartikan bahwa item dari semua pernyataan mempunyai nilai yang signifikan $(\leq 0,05)$ sehingga keseluruhan item dinyatakan valid.

\section{Uji Reliabilitas}

Uji reliabilitas menggunakan teknik alpha cronbach, dikatakan instrumen memiliki nilai reliabel yang tinggi jika nilai alpha cronbach $>0,6$. Dari hasil analisis diperoleh koefisien reliabilitas sebagai berikut.

Tabel 3 Uji Reliabilitas

\begin{tabular}{|l|c|c|c|}
\hline \multicolumn{1}{|c|}{ Variabel } & $\begin{array}{c}\text { Nilai Alpha } \\
\text { Cronbach }\end{array}$ & $\begin{array}{c}\text { Nilai } \\
\text { Kritis }\end{array}$ & Keterangan \\
\hline Persepsi harga &, 951 & 0,6 & Reliabel \\
\hline Keberagaman produk &, 965 & 0,6 & Reliabel \\
\hline Kepuasan konsumen &, 949 & 0,6 & Reliabel \\
\hline
\end{tabular}

Sumber: Lampiran Output SPSS Pengujian uji realibilitas.

Dari tabel tersebut, diperoleh nilai koefisien reliabilitas cronbach alpha pada variabel persepsi harga sebesar 0,951, variabel keberagaman produk sebesar 0,965, variable lokasi sebesar 0,928 dan variable kepuasan konsumen sebesar 0,949. Dari empat variabel diketahui nilai koefisien reliabilitas cronbach alpha lebih $>0,6$ maka disimpulkan bahwa instrumen atau kuesioner yang digunakan sangat reliabel.

\section{Uji Asumsi Klasik}

Tabel 4 Hasil Uji Asumsi Klasik

\begin{tabular}{|c|c|c|}
\hline Uji Normalitas & Hasil & Keterangan \\
\hline & asymp.sig $=0,210(>0,05)$ & Normal \\
\hline $\begin{array}{c}\text { Uji } \\
\text { Multikolinearitas }\end{array}$ & Hasil & Keterangan \\
\hline Persepsi Harga & $\mathrm{VIF}=1,051(<10)$ & $\begin{array}{l}\text { Bebas } \\
\text { Multikolinieritas }\end{array}$ \\
\hline $\begin{array}{l}\text { Keberagaman } \\
\text { Produk }\end{array}$ & $\mathrm{VIF}=1,076(<10)$ & $\begin{array}{l}\text { Bebas } \\
\text { Multikolinieritas }\end{array}$ \\
\hline Lokasi & $\mathrm{VIF}=1,114(<10)$ & $\begin{array}{l}\text { Bebas } \\
\text { Multikolinieritas }\end{array}$ \\
\hline Uji Autokorelasi & Hasil & Keterangan \\
\hline & $\mathrm{DW}=2,300$ & $\begin{array}{l}\text { Tidak terkena } \\
\text { autokorelasi }\end{array}$ \\
\hline $\begin{array}{c}\text { Uji } \\
\text { Heterokedasititas }\end{array}$ & Hasil & Keterangan \\
\hline $\begin{array}{l}\text { Scatterplot } \\
\text { terlampir }\end{array}$ & $\begin{array}{l}\text { Tidak terdapat pola yang } \\
\text { jelas, dan titik-titik di atas } \\
\text { dan di bawah angka nol } \\
\text { pada sumbu Y }\end{array}$ & $\begin{array}{l}\text { Tidak Terkena } \\
\text { Heterokedastisitas }\end{array}$ \\
\hline
\end{tabular}

Sumber: Lampiran Output SPSS Uji Asumsi Klasik (data diolah peneliti) 
Dari tabel tersebut, uji normalitas hitungan pengujian terdapat nilai asymp.sig sebesar 0,210 $(0,210>0,05)$. Sehingga disimpulkan bahwa semua data berdistribusi normal. Uji Multikolinearitas pengujian diperoleh nilai VIF untuk variabel persepsi harga 1,051 $(<10)$, variabel keberagaman produk sebesar 1,076 $(<10)$ dan variabel lokasi sebesar 1,114 $(<10)$. Maka dapat dinyatakan regresi linier berganda yang digunakan bebas multikolinieritas. Uji Autokorelasi pengujian diperoleh DW (Durbin-Watson) sebesar 2,300 (berada antara 1,55-2,46) yang berarti regresi berganda yang digunakan tidak terkena autokorelasi. Dan untuk Uji Heterokedasititas tabel tersebut menunjukkan tidak terjadinya heteroskedastisitas yang terdapat pada model regresi. Yang memiliki gambar scatterplot seperti berikut ini.

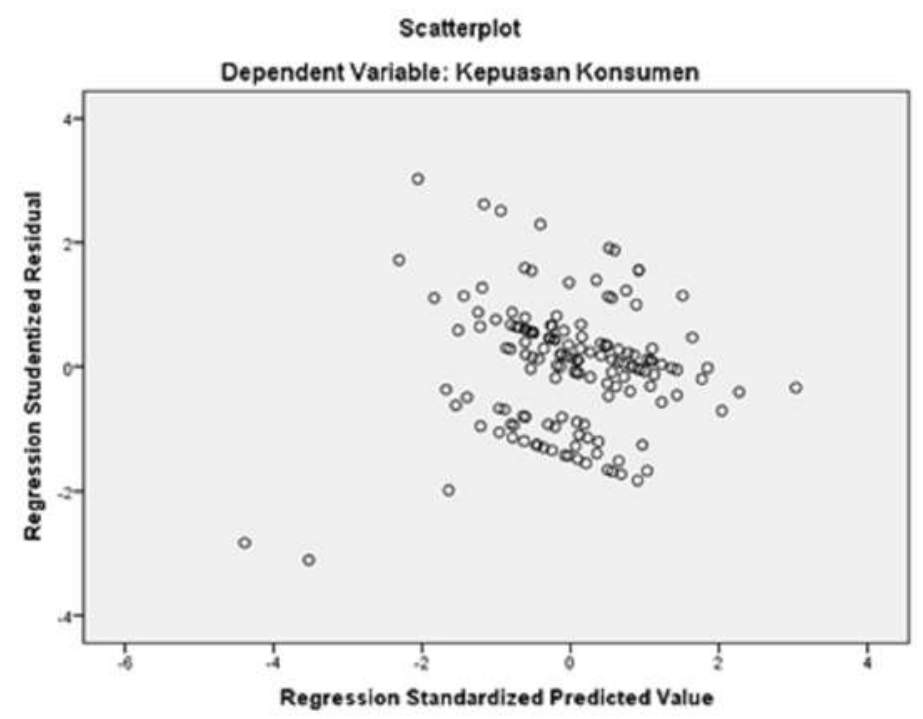

Gambar 3 Uji Heteroskedastisitas Sumber: data diolah peneliti

\section{Analisis Regresi Linier Berganda}

Setelah mengetahui nilai dari masing-masing variabel, maka langkah selanjutnya yaitu melakukan analisis regresi linier berganda. Yang bertu- juan dilakukannya untuk mempermudah perhitungan akan digunakan software SPSS versi 23, sehingga diperoleh output sebagai berikut.

Tabel 5 Uji Regresi Linier Berganda

\begin{tabular}{|c|c|c|c|c|c|}
\hline Variabel & $\begin{array}{l}\text { Unstandardized } \\
\text { Coefficients (B) }\end{array}$ & $\begin{array}{c}\text { Standardized } \\
\text { Coefficients } \\
\text { Beta }\end{array}$ & t hitung & Sig. & Keterangan \\
\hline (Constant) & 26,537 & & 5,814 & 000 & \\
\hline Persepsi Harga & , 140 & ,169 & 2,156 &, 033 & Signifikan \\
\hline Keberagaman Produk &, 133 &, 181 & 2,285 & 024 & Signifikan \\
\hline \multirow{2}{*}{$\begin{array}{l}R \\
R \text { Square } \\
F \text { hitung } \\
\text { Sig. F } \\
\alpha \\
\text { Keterangan: } \\
\text { - jumlah data } \\
\text { - Dependen variabel }\end{array}$} & & & & \multicolumn{2}{|c|}{$\begin{array}{l}=0,681 \\
=0,545 \\
=8,245 \\
=0,000 \\
=0,05\end{array}$} \\
\hline & & & & \multicolumn{2}{|c|}{$\begin{array}{l}: 150 \\
: \text { Kepuasan } \\
\text { Konsumen }\end{array}$} \\
\hline
\end{tabular}

Sumber: Output SPSS Uji Regresi Linier Berganda, Data diolah peneliti.

Tabel tersebut dapat diketahui model regresi dari keempat variabel sebagai berikut.

$$
Y=26,537+0,140 X 1+0,133 X 2+e
$$

Dapat dijelaskan arti dari koefisien regresi dari persamaan tersebut, nilai konstanta adalah 26,537. Hal ini membuktikan jika nilai variabel persepsi harga, keberagaman produk dan lokasi sama dengan nol maka nilai variabel kepuasan konsumen sebesar 26,537.

Koefisien regresi variable persepsi harga sebesar 0,140, menunjukkan besarnya pengaruh persepsi harga terhadap kepuasan konsumen. yang berarti setiap peningkatan nilai persepsi harga satu satuan maka akan menyebabkan meningkatnya kepuasan sebesar 0,140 satuan yang bertanda positif.

Koefisien regresi variabel keberagaman produk sebesar 0,133, menunjukkan besarnya pengaruh keberagaman produk terhadap kepuasan konsumen, yang berarti setiap peningkatan nilai keberagaman produk satu satuan maka akan menyebabkan meningkatnya kepuasan konsumen sebesar 0,133 satuan yang menandakan positif. 


\section{Pembahasan Hasil Penelitian}

1. Persepsi harga didapat nilai t hitung 2,156 dengan nilai signifikan 0,033 . Dari hasil tersebut dapat dinyatakan hipotesis diterima. Yang artinya persepsi harga berpengaruh positif dan signifikan terhadap kepuasan konsumen.

2. Keberagaman produk diperoleh nilai t hitung 2,285 dengan nilai signifikan 0,024. Dari hasil tersebut maka dapat dinyatakan Hipotesis diterima. Yang artinya keberagaman produk berpengaruh positif dan signifikan terhadap kepuasan konsumen.

3. Kepuasan konsumen diperoleh nilai $f$ hitung sebesar 8,245 dengan nilai signifikan sebesar 0,000. Dari hasil tersebut maka dapat dinyatakan Hipotesis diterima. Yang artinya persepsi harga, keberagaman produk dan lokasi berpengaruh positif dan signifikan terhadap kepuasan konsumen.

4. Dari pembahasan di atas, Variabel X1 (Persepsi Harga) memiliki pengaruh paling kecil yaitu 2,156 terhadap kepuasan konsumen, dibandingkan dengan variabel bebas lainnya. Penyebab terkaitnya dengan indikator persepsi harga dikarenakan adanya indikator X1.3 yaitu kesesuaian kualitas harga. Hal ini membuktikan bahwa konsumen melakukan perbandingan harga dengan Pasar lainnya pada saat mengetahui harga yang telah ditetapkan di Pasar Krisna Madubronto. Konsumen merasa apabila harga yang ditetapkan terlalu mahal dan konsumen merasa belum mendapatkan kesesuaian kualitas harga yang sesuai, sehingga konsumen tidak melakukan pembelian.

\section{SIMPULAN DAN SARAN}

\section{Simpulan}

Berdasarkan hasil analisis regresi linier berganda dan uji hipotesis terhadap hipotesis yang diajukan dalam penelitian ini, maka akhirnya penulis menyimpulkan hal-hal sebagai berikut.

a. Persepsi Harga berpengaruh positif dan signifikan terhadap kepuasan konsumen dalam membeli atau menggunakan jasa di Pasar Krisna Madubronto kabupaten Sidoarjo. Pengujian hipotesis penelitian dilakukan dengan menggunakan uji-t, di mana hasil menunjukkan bahwa hipotesis diterima dan terbukti kebenarannya. Dari hasil penelitian ini variabel persepsi harga berpengaruh paling kecil terhadap kepuasan konsumen, dibandingkan dengan variabel bebas lainnya. Penyebab terkaitnya dengan indikator persepsi harga yaitu kesesuaian kualitas harga.

b. Keberagaman produk berpengaruh positif dan signifikan terhadap kepuasan konsumen dalam membeli atau menggunakan jasa di Pasar Krisna Madubronto Kabupaten Sidoarjo. Pengujian hipotesis penelitian dilakukan dengan menggunakan uji-t, di mana hasil menunjukkan bahwa hipotesis diterima dan terbukti kebenarannya.

c. Persepsi harga, Keberagaman produk dan lokasi secara simultan berpengaruh positif dan signifikan terhadap kepuasan konsumen di Pasar Krisna Madubronto Kabupaten Sidoarjo. Pengujian hipotesis penelitian dilakukan dengan menggunakan uji-f, di mana hasil menunjukkan bahwa hipotesis diterima dan terbukti kebenarannya.

\section{Saran}

Berdasarkan simpulan penelitian yang telah diambil, maka saran-saran yang dapat diajukan yang berkaitan adalah sebagai berikut.

1. Untuk para pedagang diharapkan untuk berdagang secara jujur, meningkatkan kebera- 
gaman produk dan memberikan harga yang bersahabat sesuai yang dibutuhkan konsumen.

2. Dari penelitian ini persepsi harga memiliki pengaruh paling kecil, penyebab terkaitnya dengan indikator persepsi harga yaitu kesesuaian kualitas harga. Harga yang ditawarkan di Pasar Krisna Madubronto Kabupaten Sidoarjo berdasarkan dari tanggapan responden kurang sesuai harapan, dikarenakan mahal. Oleh karena itu sebaiknya Pasar Krisna Madubronto Kabupaten Sidoarjo memberikan harga kepada konsumennya relatif sama pada umumnya. Serta seharusnya pasaran harus dapat mempertahankan dan memperhatikan kesesuaian harga dengan baik karena itu merupakan faktor yang sangat memengaruhi keputusan pembelian konsumen dan kepuasan konsumen.

3. Dengan banyaknya pasar modern, banyak konsumen yang masih enggan berbelanja di pasar tradisional karena terbatasnya fasilitas. Untuk meningkatkan eksistensi diperlukan peranan pemerintahan daerah dan pengurus pasar dalam mengelola infrastruktur pasar tersebut.

4. Bagi peneliti selanjutnya, yang akan mengkaji lebih dalam dengan harapan objek penelitian dapat lebih diperbesar setidaknya untuk lingkup yang lebih luas. Tujuannya agar hasil penelitian dapat lebih variatif dan peneliti lebih dapat mengetahui serta membandingkan kendala yang muncul pada saat penelitian.

\section{UCAPAN TERIMA KASIH}

Puji syukur kehadirat Allah Swt. yang telah memberikan karunia dan kesempatan kepada peneliti sehingga penulis bisa menyelesaikan Artikel dengan baik. Shalawat beserta salam semoga selalu tercurahkan kepada Rasulullah shallallahu alaihi wasallam yang membawa kita kepada zaman yang penuh dengan cahaya Islam.

Penulis menyadari tidak mampu menyelesaikan artikel ini tanpa ada dorongan, bantuan dan kerjasama dari pihak-pihak yang sangat berperan dalam pengerjaan artikel ini. Ucapan terima kasih yang dalam, kepada Wulan Purnamasari, S.E., M.S.M. selaku Kaprodi Ekonomi Manajemen Universitas Maarif Hasyim Latif Sidoarjo. Dr. H.Soenarto, Ak., M.Si. selaku pembimbing yang banyak membagikan nasihat dan bimbingan serta arahan kepada penulis. Ayahanda, Ibunda dan suami saya terima kasih motivasi dan bimbingannya, doa dukungannya serta terima kasih atas perhatian dan kasih sayang yang diberi selama ini.

Tak lupa saya berterima kasih kepada rekan kerja dan sahabat seperjuangan Manajemen A sore yang selalu menghibur ketika penat, serta telah menyemangati setiap hari dalam mengerjakan tugas-tugas kuliah hingga selesai empat tahun ini.

\section{DAFTAR RUJUKAN}

Fure, Hendra. 2013. Lokasi, Keberagaman Produk, Harga dan Kualitas Pelayanan Pengaruhnya Terhadap Minat Beli pada Pasar Tradisional Bersehati Calaca. Jurnal Manajemen. Manado: FE-Universitas Sam Ratulangi.

Kotler, Philip and Kevein Lane Keller. 2009. Marketing Management. 13th ed. New Jersey: Pearson Prentice Hall.

Sugiyono. 2009. Metode Penelitian Kuantitatif, Kualitatif, dan RひD. Bandung: Alfabeta. Swasta, Basu dan Irawan 2003. Manajemen Pemasaran Modern Analisis Perilaku Konsumen. Yogyakarta: Liberty. 
Tedjakusuma, Hartini, dan Muryani. 2008. Analisis Faktor-Faktor yang Memengarubi Perilaku Konsumen dalam Pembelian Air Minum Mineral di Kotamadya Surabaya. Fakultas Ekonomi Universitas Airlangga.
Zeithmal and Bitner. 2000. Service Marketing Integrating Customer Focus Across The Firm, Second Edition Hill. New York: McGraw. 